\title{
Comparative evaluation of fish, crayfish waste, meat and blood meal for broiler production
}

${ }^{2}$ Ukoha O. A., ${ }^{1}$ Nsa, E. E., * ${ }^{2}$ Onunkwo, D. N. and ${ }^{2}$ Ezike, J. C.

${ }^{\prime}$ Department of Animal Science, University of Calabar, Cross River State

${ }^{2}$ College of Animal Science and Animal Production,

Michael Okpara University of Agriculture, Umudike, Abia State, Nigeria

Abstract

*Corresponding author: donunkwo1@gmail.com; +2348033388622

The effect of different animal protein sources in broiler production was investigated. 300 seven-day old broilers of equal average initial weight were randomly allotted into five treatment groups with three replications of 20 birds each and at the end of 28 days, birds were weighed again and re-randomized to the five treatment groups with three replicates of 16 birds each. The diets consisted of four animal proteins. Treatment 1 (Control) had no animal protein while diet 2, 3, 4 and 5 had 4\% fish meal, 4\% crayfish waste meal, 4\% blood meal and $4 \%$ meat meal, respectively. The study was conducted for 56 days with 28 days starter phase and 28days finisher phase. Parameters evaluated were proximate composition of test ingredients, growth performance of experimental animals, nutrient digestibility and economic analysis. The results showed blood meal had the highest $(P<0.05)$ crude protein level (77.68\%) followed by fish meal (54.53\%), crayfish waste (48.08\%) and meat meal (41.67\%). Cray fish waste meal had the highest $(P<0.05)$ crude fibre $(6.07 \%)$ while blood meal had the least (2.98\%). Fish meal had the highest ether extract (5.99\%) followed by crayfish waste meal (4.03\%), meat meal (3.67\%) and blood meal (3.93\%). There were nonsignificant $(P<0.05)$ differences in feed intake during both starter and finisher phases across the treatment groups. Blood meal significantly $(P<0.05)$ depressed final live weight, weight gain, feed conversion ratio and protein efficiency ratio while other ingredients showed $(P>0.05)$ similarities in the above parameters apart from in protein efficiency ratio for which meat meal only showed significant $(P<0.05)$ depression. The least cost per $\mathrm{kg}$ feed and least cost per kg weight gain (naira) were observed with birds on crayfish diets. There was better $(P<0.05)$ digestibility of crude protein by birds on treatment diets 1 and 2 followed by 3 and 4 while birds than on treatment diet5 had the least value (58.10\%). Conclusively, the use of crayfish waste meal in broiler starter diets and combined proteins in broiler fisher diets should be encouraged.

\section{Introduction}

Animal concentrates are known to be good source of essential amino acids, essential fatty acids, and calcium. Phosphorus, Bcomplex vitamins especially $\mathrm{B}_{12}$ and riboflavin and some desirable trace minerals including manganese, and iodine. The presence of a growth factor collectively known as animal protein factor (APF) makes animal concentrates a compulsory ingredient in poultry feeds for optimum production performance (Ravinder and Qudratallah, 1996).
The most conventional animal protein sources in the tropics are fish meal and blood meal. However, the extremely high prices of these ingredients coupled with their poor shelf-life has increased the feeding cost viz a viz the total cost of livestock production, especially poultry and pigs (Nsa et al., 2009).

Marine fish are a good source of fluoride and the richest source of iodine in the diets. It is also rich in calcium and phosphorus, when eaten whole. Fish oils are good sources of vitamins A and D (Olomu, 1995). 


\section{Comparative evaluation of fish, crayfish waste, meat and blood meal}

With all these qualities Olomu (1995) recommended 10\% Maximum level of inclusion for pig starters, for older broiler chicks and ducklings and older turkeys up to 12 weeks of age maximum level should be $7.5 \%$ and $5 \%$ for laying and breeding chickens. Cray fish is among crustaceans; like shrimps, prawns, crabs and lobsters. They are good sources of calcium, iron, riboflavin and niacin but seem to be deficient in thiamine, vitamins A, D and C. (Olomu, 1995). The crayfish waste used for this experiment contained little of these crustaceans and mostly their tendrils and appendages. Meat meal which is the rendered products from animal (especially mammals) tissues excluding bone, blood, hair, hoof, horn and hide trimmings (Olomu, 1995) is a rich source of animal protein in broiler diets (Nsa et al., 2009). Meat meal should not be used at levels beyond $15 \%$, for pigs, levels should be restricted to $2 \%$ or less in starter diets, 3$5 \%$ in lactation diets, $5-7 \%$ in grower and gestation diets and up to $10 \%$ level can be used in the diets meant for poultry birds (Olomu, 1995). Blood meal in particular is said to be deficient in isoleucine and glycine with attendant poor biological value and highly unpalatable when added in large amount to livestock feeds especially poultry feeds (Obioha, 1992; McDonald et al., 1994). While fish meal, though of high biological value, is scarce and very costly. It is used mostly in diets of young animals whose demand for protein and the essential amino acids is particularly high. In older animals, the level of animal protein is always moderated and may be entirely eliminated in diets for those in the last stages of fattening, partly for economic reasons and to remove any possibility of a fatty taint in the finisher carcass (Obioha, 1992; McDonald et al., 1994).

According to Udedibie et al. (1988); Nwokoro (1993) and Ravinder, et al. (1996), animal by-products like meat meal, liver residue meal, poultry offal meal, waste products from poultry eviscerating plants, though only available in small quantities have served as good animal concentrates in poultry and livestock rations (Atteh and Ologbenla, 1993), as well as house fly pupae meal (El-Boushy, 1991), Shrimp waste meal (Fanimo et al., 1996) and crustacean meal (Ravinder and Qudratulla, 1996).

The objective of the study was to determine the effects of incorporating protein from sea and land animals in broiler bird's diets on the growth performance and economy of feed utilization.

\section{Materials and methods Experimental site}

The experiment was carried out at the deep litter poultry unit of the Teaching and Research Unit of Department of Animal Science, University of Calabar, Nigeria. The climatic records during the period of the experiment showed the average relative temperature and humidity at $29.760 \mathrm{C}$ and $73.57 \%$ respectively (Sule, 2007).

\section{Experimental birds}

Three hundred 7 day old Nora broiler chicks obtained from a commercial hatchery in Ibadan were used for the study. The birds were divided into five treatment groups with three replicates of 20 birds each and fed with the experimental diets, at the end of starter phase that lasted for 28 days, birds were further weighed and re-randomized to start the finisher phase which also lasted for another 28 days. Water and feeds were given ad libitum throughout the experimental period (56 days).

\section{Experimental diets}

Six experimental diets were formulated such that the control (T1) contained 4\% fish meal (Control). Treatment diets 2 contained $1 \%$ of each of the test ingredients; fish meal, crayfish waste meal, blood meal and meat meal while treatment diets 3,4 and 5 contained $4 \%$ of crayfish meal, blood meal 


\section{Ukoha, Nsa, Onunkwo and Ezike}

and meat meal respectively (Table 2). Fish meal was made from herring fishes bought from the fishermen, Cray fish dust was all gotten from Nsidung Market in Calabar while meat scrap and blood meal from cow and goat were gotten from the abattoir within Calabar municipality. All ingredients were subjected to heat treatment by oven drying at a temperature of $60^{\circ} \mathrm{C}$ for 72 hours after being ground in hammer mill.

\section{Proximate analysis}

Samples of each test ingredient were analyzed for their proximate composition (AOAC, 1995). Nitrogen free extract (NFE) was determined by difference. The gross energy of the samples was assayed using the adiabatic oxygen bomb calorimetric technique.

\section{Experimental design and digestibility studies}

The experiment was a completely randomized design. At 8 weeks of age, 4 birds per replicate were randomly selected and kept in metabolic cages. The birds were fed with the same diets offered during the feeding trial. Records on feed intake and excreta were taken on a daily basis with the use of electronic weighing balance. The daily excreta were dried to a constant weight of $80^{\circ} \mathrm{C}$ in the oven. The dried samples were ground in a hammer mill and stored at room temperature for proximate analysis. The digestibility trial lasted 10days: 7 days for excreta collection and 3 days for acclimatization.

\section{Statistical analysis}

All data were subjected to analysis of variance, and the means were separated using Duncan's Multiple Range Test as outlined by Daniel (1991).

\section{Results and discussion}

The analysed chemical composition of the test ingredients are presented in Table 1. Blood meal had the highest $(\mathrm{P}<0.05)$ crude protein level $(77.68 \%)$ than fish meal $(54.53 \%)$, crayfish waste $(48.06 \%)$ and meat meal $(41.67 \%)$ in that order. Cray fish waste and meat meal had statistical similar values that were significantly $(\mathrm{P}>0.05)$ lower than fish meal. The high level of blood meal value is close to values reported by Olomu (2005); Reddy (2007); Nsa et al. (2009). The seemingly lower level of crude protein value when compared to fish meal could be as a result of some debris like leaves and sticks a typical nature of crayfish waste. This agrees with the report of Fanimo et al. (2016). Cray fish recorded the highest value of crude fibre $(6.07 \%)$, a value that was close $5.12 \%$ reported by Nsa et al. (2009). Other ingredients apart from blood meal that had significantly $(\mathrm{P}<0.05)$ lower, had values that were not significantly $(\mathrm{P}<0.05)$ different. The seemingly observed higher crude fibre content in crayfish waste could also be attributed to the content of foreign materials like leaves, sticks and so on (Nsa et al., 2009). Fish meal and meat meal had the highest but similar ether extract values that were higher than both Cray fish dust and blood meal. This observation could be as a result of abdominal fat of both whole fish and animal scrap that was included in both fish and meat meals.

\begin{tabular}{|c|c|c|c|c|c|c|}
\hline Components (\%) & Fish meal & $\begin{array}{l}\text { Combined } \\
\text { proteins }\end{array}$ & $\begin{array}{l}\text { Crayfish } \\
\text { waste meal }\end{array}$ & $\begin{array}{l}\text { Blood } \\
\text { meal }\end{array}$ & $\begin{array}{l}\text { Meat } \\
\text { meal }\end{array}$ & SEM \\
\hline Dry matter & 81.22 & 80.91 & 83.44 & 81.67 & 80.36 & 1.39 \\
\hline Crude protein & $54.53^{\mathrm{c}}$ & $63.97^{\mathrm{b}}$ & $48.08^{\mathrm{d}}$ & $77.68^{\mathrm{a}}$ & $41.67^{\mathrm{d}}$ & 0.98 \\
\hline Crude fibre & $3.97^{\mathrm{bc}}$ & $5.08^{\mathrm{ab}}$ & $6.07^{\mathrm{a}}$ & $2.98^{\mathrm{c}}$ & $4.50^{\mathrm{b}}$ & 0.64 \\
\hline Ether extract & $5.99^{\mathrm{a}}$ & $4.58^{\mathrm{b}}$ & $4.03^{b c}$ & $3.67^{\mathrm{c}}$ & $3.63^{\mathrm{c}}$ & 0.53 \\
\hline Ash & 7.91 & 7.10 & 6.55 & 5.02 & 6.79 & 0.09 \\
\hline NFE & $27.60^{\mathrm{c}}$ & $19.27^{\mathrm{d}}$ & $35.27^{\mathrm{b}}$ & $10.65^{\mathrm{e}}$ & $43.41^{\mathrm{a}}$ & 1.12 \\
\hline Gross energy (Kcal/g) & 3.98 & 3.69 & 3.91 & 3.67 & 3.66 & 0.02 \\
\hline
\end{tabular}




\section{Comparative evaluation of fish, crayfish waste, meat and blood meal}

There were no significant differences $(\mathrm{P}>0.05)$ in feed intake among treatment means at the starter and finisher phases, despite the lower level of intake witnessed by birds on treatment diet 4 (blood meal) as shown in Table 2. This means there was no inhibition in the consumption of any of the diets, and also each ingredient in all the diets was included at the same level and received the same treatment

Any differences observed in other performance parameters could therefore only arise from the utilization of the diets. The diets containing blood meal T5 at the starter phase significantly $(\mathrm{P}>0.05)$ depressed final body weight (513.20g,), weight gain $(19.40 \mathrm{~g})$, protein efficiency ratio (1.37) and encouraged the poorest feed conversion ratio (3.14) while other diets; $1,2,3$ and 4 had similar $(\mathrm{P}>0.05)$ values.

As observed in the starter phase there was no significant $(\mathrm{P}>0.05)$ differences in treatment diets at the finisher phase except with birds on blood meal diets(T5) that showed depressed final body weight $(1968.10 \mathrm{~g})$, weight gain $(20.97 \mathrm{~g})$, protein efficiency ratio (0.98) and encouraged the poorest feed conversion ratio (4.63).

The poor performance of birds on blood meal diet agrees with the report of Nwokoro (1993); Nsa et al. (2009), who attributed it to be due to the unbalanced amino acid profile of blood meal. Blood meal is said to be low in isoleucine, tryptophan and glycine than either fish meal, Cray fish waste or meat meal. These essential amino acids are very necessary for bird's growth performances (Reddy, 2001). Fish meal, cray fish meal and meat meal are noted to be rich and balanced in amino acid, also there are rich in minerals and high biological value, these could be responsible for the better performance of birds when compared to birds on diets with blood meal (McDonald et al., 1994; Udedibie et al., 1988; Ojewola et al., 2005).

The improved values of protein efficiency

Table 2 Performance of broiler chickens fed different protein sources

\begin{tabular}{lllllll}
\hline Ingredients & $\mathbf{1}$ & $\mathbf{2}$ & $\mathbf{3}$ & $\mathbf{4}$ & $\mathbf{5}$ \\
& Fish meal & Combined & $\begin{array}{l}\text { Crayfish } \\
\text { waste meal }\end{array}$ & $\begin{array}{l}\text { Meat } \\
\text { meal }\end{array}$ & blood meal & SEM \\
\hline Initial weights(g) & 90.66 & 91.02 & 90.80 & 91.00 & 91.10 & 2.41 \\
Final weight(g) & 797.55 & 790.50 & 760.15 & 755.10 & 513.20 & 9.26 \\
Daily feed intake(g) & 70.11 & 67.38 & 69.31 & 69.40 & 61.00 & 2.19 \\
Daily weight gain(g) & $25.77^{\mathrm{a}}$ & $25.18^{\mathrm{a}}$ & $24.91^{\mathrm{a}}$ & $24.69^{\mathrm{a}}$ & $19.40^{\mathrm{b}}$ & 1.03 \\
Feed conversion ratio & $2.72^{\mathrm{b}}$ & $2.68^{\mathrm{b}}$ & $2.78^{\mathrm{b}}$ & $2.81^{\mathrm{b}}$ & $3.14^{\mathrm{a}}$ & 0.06 \\
Daily protein intake(g) & $15.31^{\mathrm{a}}$ & $15.57^{\mathrm{a}}$ & $15.02^{\mathrm{a}}$ & $15.05^{\mathrm{a}}$ & $14.19^{\mathrm{b}}$ & 0.26 \\
Protein efficiency ratio & $1.68^{\mathrm{a}}$ & $1.62^{\mathrm{a}}$ & $1.66^{\mathrm{a}}$ & $1.64^{\mathrm{a}}$ & $1.37^{\mathrm{b}}$ & 0.08 \\
Feed cost(N/kg) & 112.60 & 108.12 & 99.87 & 109.73 & 100.18 & 4.59 \\
N/kg meat produced & $306.34^{\mathrm{a}}$ & $289.32^{\mathrm{b}}$ & $277.88^{\mathrm{c}}$ & $308.35^{\mathrm{a}}$ & $315.00^{\mathrm{a}}$ & 4.41 \\
Cost reduction (\%) & - & $5.56^{\mathrm{b}}$ & $9.29^{\mathrm{a}}$ & $-0.66^{\mathrm{c}}$ & $-2.83^{\mathrm{d}}$ & 0.01 \\
Finisher phase & & & & & & \\
Initial weight(g) & 792.15 & 790.72 & 786.51 & 787.22 & 789.14 & 2.83 \\
Final weight(g) & 2885.00 & 2755.50 & 2490.15 & 2515.76 & 1969.10 & 11.01 \\
Daily weight gain(g) & 29.74 & 28.92 & 27.18 & 27.60 & 20.97 & 0.17 \\
Daily feed intake(g) & 105.66 & 101.11 & 104.92 & 102.84 & 96.96 & 6.66 \\
Feed conversion ratio & $3.55^{\mathrm{c}}$ & $3.50^{\mathrm{c}}$ & $3.86^{\mathrm{b}}$ & $3.73^{\mathrm{b}}$ & $4.63^{\mathrm{a}}$ & 0.04 \\
Daily protein intake(g) & 23.07 & 22.13 & 22.76 & 22.30 & 21.32 & 1.53 \\
Protein efficiency ratio & 1.29 & 1.31 & 1.19 & 1.24 & 0.98 & 0.02 \\
Feed cost(N/kg) & 102.50 & 99.87 & 101.66 & 99.97 & 96.18 & 6.91 \\
Cost/kg weight gain(N) & $364.16^{\mathrm{bc}}$ & $349.17^{\mathrm{c}}$ & $392.43^{\mathrm{b}}$ & $372.89^{\mathrm{b}}$ & $441.71^{\mathrm{a}}$ & 8.18 \\
Cost reduction (\%) & - & $4.12^{\mathrm{a}}$ & $-7.76^{\mathrm{b}}$ & $-2.40^{\mathrm{b}}$ & $-21.30^{\mathrm{c}}$ & 0.01 \\
\hline
\end{tabular}




\section{Ukoha, Nsa, Onunkwo and Ezike}

ratio with birds diets containing fish meal and cray fish meals at the starter phase could be attributed to additional content of Omega 3 in marine protein sources which according to Olomu (1995) helps in improving protein utilization by animals. However, at the finisher phase this assumption did not hold probable due to the fact that mature birds can utilise effectively varied sources of animal protein sources more effectively (Nsa et al. 2012).

The economic analysis revealed that the cost price per $\mathrm{kg}$ of feed was N112.60, N108.12, N99.87, N109.73 and N100.18 for treatment diets $1,2,3,4$ and 5 respectively during the starter phase. And at the finisher phase; N102.50, N99.87, N101.66, N99.97 andN96.18 for treatment diets $1,2,3,4$ and 5 respectively. The observed trend of lower cost price of feed with crayfish dust, meat meal and blood meal is because they are either sold at lower prices or discarded. Apart from diets with cray fish dust that gave a better $(\mathrm{P}<0.05)$ cost per $\mathrm{kg}(\mathrm{N} / \mathrm{kg})$ meat produced. Other protein ingredients; blood meal and meat meal did not encourage high $\mathrm{N} / \mathrm{kg}$ meat produced. Cray fish waste is either discarded or sold at a cheap price when compared to other animal sources, likewise blood meal. However, a better economic of feed was achieved since birds could not effectively utilized blood meal for growth. The apparent digestibility trial (Table 3) showed that all the nutrients apparent from crude protein were similar $\mathrm{P}<0.05$ ) in values. The crude protein was better utilised by birds in treatment diets 1 and 2, followed by treatments diets 3 and 4 and least value by birds in treatment diet 5 . The observed depressed protein digestibility by birds on diets containing only blood meal as the only protein source could be due to the in-balance in amino acid in the diet. Imbalance in amino acid could cause elevated blood urea concentration (Eggum, 1970). Blood urea level especially in monogastric by quantity, quality, and proximity of the proceeding meal, which increase mostly after eating (Eduche et al., 2007). Urea is a function of protein quality. High urea indicates low protein quality fed which in turn produce low give poor protein digestibility.

Table 3. Apparent digestibility of nutrient (\%) by broiler birds fed different animal protein sources

\begin{tabular}{|c|c|c|c|c|c|c|}
\hline Parameters & $\begin{array}{l}1 \\
\text { Fishmeal }\end{array}$ & $\begin{array}{l}2 \\
\text { Combined } \\
\text { protein }\end{array}$ & $\begin{array}{l}3 \\
\text { Crayfish } \\
\text { waste meal }\end{array}$ & $\begin{array}{l}4 \\
\text { Meat meal }\end{array}$ & $\begin{array}{l}5 \\
\text { Blood meal }\end{array}$ & SEM \\
\hline Dry matter digestibility & 61.12 & 61.00 & 59.87 & 54.54 & 50.81 & 3.12 \\
\hline Crude protein digestibility & $70.47^{\mathrm{a}}$ & $67.00^{\mathrm{ab}}$ & $63.58^{\mathrm{b}}$ & $64.06^{\mathrm{b}}$ & $58.10^{\mathrm{c}}$ & 3.11 \\
\hline Ash digestibility & 52.16 & 55.01 & 60.98 & 56.66 & 60.22 & 4.52 \\
\hline Ether extract digestibility & 64.81 & 63.49 & 61.23 & 64.13 & 60.14 & 2.83 \\
\hline NFE digestibility & 58.93 & 52.70 & 69.00 & 69.64 & 65.02 & 3.23 \\
\hline
\end{tabular}

Conclusively, it can be inferred that apart from the fish meal, the use of cray fish waste meal in place of other animal protein sources should be encouraged mostly during the starter phase of broiler production as it gives least cost savings. At finisher phase the than one animal protein sources should be encouraged.
References

A. O. A. C. 1995. Association of Official Analytical Chemists. Official Methods of Analysis. Washington DC.

Atteh, J. O. and Oyedeyi, J. O. 1990. The replacement value of maggot for groundnut cake in broiler diet. Centre point, 4:39-46. 
Atteh, J. O. and Ologbenla, F. D. 1993. Replacement of fish meal with maggots in broiler diets: effects on performance and nutrient retention. Nigerian Journal of. Animal Production. 20:44-49.

Daniel, W. W. 1991.Biostatistics: $A$ foundation for analysis in the health Sciences. Wisky and Sons, New York.

El-Boushy, E. E. 1991. Housefly pupae as poultry manure converters for animal feed. A review: $B \quad i \quad o$ resources Technology. 38:45-49.

Fanimo, A. O., Mudama, E, Umukoro, T. O. and Oduguwa, O. O. 1996. Substitution of shrimp waste meals for fish meal in broiler chicken rations. Tropical Agriculture. (Trinidad) 73:200205.

McDonald, P., Edwards, R. A. and Greenhalgh, J. F. D. 1994. Animal Nutrition. $4^{\text {th }}$ Edition, Longman $\quad \mathrm{P} \mathrm{u}$ bli s h e r s Limited, England.

Nwokoro, S. O. 1993. Effects of blood meals, chicken offal meal and fish meal as source of methionine and lysine in starter cockrels diets. Nigerian Journal of Animal Production. 20:86-95.

Obioha, F. C. 1992. A guide to poultry production in the Tropics. ACENA Publishers Limited.
Ravinder, V. R. and Qudratullah, S. 1996. Squilla, a novel animal protein. Feed International. 32:54-67.

Udedibie, A. B.I., Anyanwu, G., Ukpai, U. I. and Oyet, A. J. 1998. Poultry offal meal as a protein supplement for laying hens and finisher broilers. Nigerian Journal of Animal Production. 15"103109.

Nsa, E. E., Akpan, I. A., Okon, B. and Anya, M. I. 2009. Comparative evaluation of five protein concentrates in broiler finisher diets. Proccedings of $14^{\text {th }}$ annual conference of Animal Science Association of Nigeria (Lautech)

Olomu, J. M. 1995. Monogastric animal nutrition. Principles and practice. A Jachem Press.

Reddy, D. V. 2007. Applied Nutrition; livestock, poultry, human, pet and laboratory Animal Nutrition. Vijay Publishers.

Received: $19^{\text {th }}$ September 2018 Accepted: $21^{\text {st }}$ December, 2018 